\title{
Improving Reading Performance for Non-English-Majored Graduate Students: Combining a Know-Want-Learn Plus Model of Meta-Cognitive Reading Strategy Instruction and Internet-Based Language Laboratory Support
}

\author{
Yougen $\mathrm{Lou}^{1 *}$, Pei Xu${ }^{2}$ \\ ${ }^{1}$ School of Foreign Studies, Yangtze University, Jingzhou, China \\ ${ }^{2}$ Paotong Elementary School, Wuhan, China \\ Email: *louyougen@163.com
}

Received 11 January 2016; accepted 25 February 2016; published 29 February 2016

Copyright (C) 2016 by author and Scientific Research Publishing Inc.

This work is licensed under the Creative Commons Attribution International License (CC BY). http://creativecommons.org/licenses/by/4.0/

\section{(c) (i) Open Access}

\begin{abstract}
This paper reviewed a one-term experiment on integrating internet-based language laboratory (IBLL) in teaching reading with the know-want-learn (KWL) plus model to first-year non-Englishmajored graduate students from Yangtze University. Subjects in this study consisted of 41 nonEnglish-majored graduate students in the control group (CG) and 41 non-English-majored graduate students in the experimental group (EG). The results showed that 1) compared with a teacherdominated approach for CG, internet-based language laboratory with KWL plus model meta-cognitive reading strategy instruction for EG did a better job in enhancing students' reading skills; 2) There were significant differences between males in CG and EG and females in CG and EG; 3) Students in EG held the positive response for the combined instruction.
\end{abstract}

\section{Keywords}

KWL Plus Model, Reading Strategy Instruction, Internet-Based Language Laboratory

\footnotetext{
${ }^{*}$ Corresponding author.
} 


\section{Introduction}

In the past few years most key universities have enlarged their enrollment with the rate of 35\% every year (Wang Yuwen et al., 2003), which has given rise to a serious shortage of English teachers and the difficulties to guarantee and improve the quality of college students and graduates' academic level though English reading. In order to solve the first problem (the serious shortage of English teachers), most universities and colleges have implemented large-size group teaching. However, in the large-size class, students are short of opportunities to practice English they learned. And students will have no opportunity to enhance English productive skills of speaking, writing and translating in a teacher-centered classroom. Faced the problem, different universities and colleges have taken different measure to solve it in China. For example, in 1998, an experiment with computerassisted language learning (CALL) was conducted by Liu and Jia to teach their non-English-majored graduate students by using the CD-Rom version of the college English textbook in a university in Guangzhou. Another example, in 2003, an experiment with computer-assisted language learning (CALL) was conducted by Wang Yuwen in teaching intensive reading to their graduate students in Beijing Institute of Technology. CALL could be served differently in the field of language teaching and language learning and has been proved to be an effective tool for improving the quality of language education (Sullivan, 1993; Warschauer, 1998; Shen, 1999). And now internet-based language laboratory (IBLL) was popularly used in teaching students’ English in more universities. There were many researches (Nilgün Açık Önkaú, 2009; Yi Lan \& Gao Xiaoying, 2011; Mohd Khalid Ustatia \& Izaham Shah Ismail, 2013) on language laboratory. IBLL could be served differently in the field of language teaching and language learning, but there were few researches on IBLL used in teaching non-Englishmajored graduate students' English reading. As we know, reading is a useful and important method for people to obtain the information in both the first language (L1) and the second language (L2). But many L2 readers lack appropriate reading strategies. Instead, they usually focus on word recognition and rely heavily on a word-forword translation strategy (Rusciolelli, 1995). The increasing evidence on language learners' strategy use and learning success from recent research (Chamot, 1995; Oxford, 2001) has motivated wide practices of strategy instruction in both L1 and L2 learning contexts. However, attempts on strategy instruction in literature focused mainly on one or two individual strategies at a time and the long-term effects of such instruction were also inconclusive (Ellis, 2008; Vandergrift \& Tafaghodtari, 2010). Researchers Auerbach and Paxton (1997) observed college level ESL students who were in the beginning stages of developing their reading skills and the behaviors of these students when reading for academic purposes. They concluded that these learners felt that they had to know all the words in a text in order to understand it, relied heavily on the dictionary, were unable to transfer productive LI [native language] strategies or positive feelings about reading, spent long hours laboring over sentence-by-sentence translation, and attributed their difficulties to a lack of English proficiency (p. 238). KWL plus was a fourth-stage instructional process scaffolding learners to reflect on what they know, what they want to know, and what they have learned during their reading process (Ogle, 2009). In order to solve the second problem (the difficulties to guarantee and improve the quality of college students and graduates' academic level though English reading), the author tried to adopt the KWL plus model of meta-cognitive reading strategy instruction with the support of IBLL.

The purpose of this study is to investigate the impact of integrating BLL in KWL plus model of reading strategy instruction for non-English-majored graduate students. More specifically, this study attempts to answer the following questions:

1) Compared with a teacher-dominated approach with the control group (CG), has the KWL plus model of meta-cognitive reading strategy instruction through IBLL with the experiment group (EG) done a better job in improving students' reading comprehension and the meta-cognition in reading?

2) Are there significant differences between males and females as a teacher-dominated approach with CG is compared with the KWL plus model of reading strategy instruction in IBLL with EG?

3) What is non-English-majored graduate students’ response towards this combination?

\section{Literature Review}

\subsection{KWL Plus}

KWL is a three-stage instructional framework first designed by Ogle (1986) for teachers to guide students with a systematic approach to their reading processes. In KWL (Ogle, 1986: p. 564), “K” stands for asking students 
what they know about a topic when the teacher initiates a lesson. During this preliminary discussion, students' prior knowledge is stimulated and different opinions and experiences about the topic are pooled. Such practices allow students to frame key questions they want to investigate in the current reading - the " $w$ " in KWL. These questions, in turn, encourage learners to plan for the coming reading and monitor their comprehension during the reading process. The " $\mathrm{L}$ " represents what students have learned and still need to Learn after the reading.

To help students better expand their knowledge and to engage them in reflective thinking while reading, Carr and Ogle (1987) extended the KWL model to include Summary as its fourth part. At this part, students are encouraged to reorganize what they have learned with the assistance of a graphic organizer. Based on the graphic organizer, a final written summary is required as an additional opportunity for students to consolidate their learning. The extended model was later labeled KWL Plus (Carr \& Ogle, 1987; Ogle, 2009) or KWL+ (Ogle, 2007).

\subsection{Meta-Cognition and Reading Strategy Instruction}

Meta-cognition was originally coined by Flavell (1976) to refer to the knowledge and regulation of one's cognition. Later on, in the field of second/foreign language acquisition, the development of students' meta-cognition, or their ability to understand and orchestrate their own learning process, has been urged by a number of language learning strategy researchers (Anderson, 2002; Rubin, 2001; Wenden, 2000). For reading, researchers share similar viewpoints that meta-cognitive strategy training should be a central component of reading instruction (Grabe, 2009). Good readers often routinize a combined use of a few strategies working well for them (Grabe, 2009). In the book, Grabe (2009: p. 231) listed eleven empirically supported instructional approaches engaged multiple-strategy instruction. Among these meta-cognitive strategy instructions, two, in particular, stressed that less proficient learners benefited more from meta-cognitive instruction than their comparatively more proficient peers (McKeown \& Gentilucci, 2007; Shang \& Chang-Chien, 2010). Jiuhuan Huang and dia Newbern (2012) studied the effects of meta-cognitive reading strategy instruction on reading performance of adult ESL learners with limited English and literacy skills.

\section{Research Methods}

\subsection{Subjects}

In September 2015, 82 first-year non-English-majored graduates in 2 classes from Yangtze University were as the subjects. Their majors are chemistry, agriculture, plant protection, animal medicine, animal science and biological technology participated in this study. Among the 82 subjects, they were 43 females and 39 males, average age 23 with Chinese. All 82 students who had learned graduate English first semester and had passed CET4 were randomly divided into the control group (CG 41 students) whose English entrance examination scores vary from 50 to 110 and the experiment group (EG 41 students). Their level of education, family background, age, personality and life experiences and other factors were same, that was to say, their overall learning and cognitive abilities were almost equal. All 82 students were taught by the first author.

\subsection{Graduate English Course}

All non-English-majored graduate students in Yangtze University were required to receive one semesters' compulsory graduate English course in the first year when they were at university. The 15-week graduate English course was divided into three parts: Listening and Speaking, Reading and Writing, Teacher-Guided Autonomous Learning. Students were to have listening and speaking English three hours a week fifteen weeks, whereas English Reading and Writing, Teacher-Guided Autonomous Learning three hours a week for fifteen weeks. The same instructor was responsible for all three parts' English learning of one class. The textbook for non- English-majored graduate students in the English reading and writing class was published by Foreign Language Teaching and Research Press. In total, ten units were covered in Reading and Writing 1, and each unit included two passages (Text A and Text B) of the same topic and exercises. Usually, the instruction given by the teacher in the reading classes included three steps. Firstly, the teacher would ask a few questions to lead in the topic of that unit for text reading. Secondly, students would be asked to read Text A in that unit. After reading Text A, 
the teacher checked students' understanding of Text A by comprehension exercises followed the passage. Finally, vocabulary exercises and close exercises were done together by the teacher and students. Text B was provided to students for self-study in their autonomous learning session without the teacher's specific guidelines.

\subsection{Meta-Cognitive Strategy Training Program in IBLL}

For students in CG, the regular non-English-major graduate English lessons with the teacher-centered grammar-translation method were taught in English Reading and Writing, and Students Autonomous Learning sessions. Over the one-semester (15-week) period, the model of KWL plus was regarded as the major approach in this meta-cognitive strategy instruction in IBLL. The two passages in one unit of the reading and writing textbook were given as materials for this training. Text A was used for the teacher modeling of strategy use in the Reading session and Text B for students' practice in the autonomous learning session. One cycle of strategy training to the completed learning of one unit made up of scaffolding KWL plus with Text A and students' practice with Text B in IBLL For the teacher's intervention (scaffolding KWL plus with Text A), the teacher showed students how to move the information known by students (K), through students' wanting to know (W) with generating questions to be answered during reading passages or through the help of IBLL to look for information related to questions, and to students having learned by monitoring comprehension and noting down answers, and finally reach Plus level by summarizing the passage or the learning in IBLL. Although the KWL plus model was used through this whole semester, each round of training had a deliberate focus on one particular part of the cycling. For instance, each of the four main reading strategies trained in the KWL plus model constituted a focus on different rounds of training respectively in IBLL.

\subsection{Data Collection and Data Analysis}

In order to check the effects of KWL plus strategy training on non-English-major graduates' reading ability, three types of instruments were employed in this study: reading comprehension tests; meta-cognitive strategy use questionnaire; and interview.

Reading comprehension test. Non-English-major graduates' reading comprehension tests were measured by pre- and post-tests. In order to avoid the interference of the author's subjectivity in test design and scoring, reading comprehension tests were measured directly by the part of reading comprehension in a nationwide standard test new version College English Test six (CET 6 710). Non-English-major graduates' reading comprehension scores were collected. The reading comprehension section made up of three parts. Part one was a passage with ten blanks requiring students to select one word for each blank from a list of choices given in a word bank and any of the words in the word bank may not be used more than once. Part two was fast reading requiring students to read a passage with ten statements attached to it and answer 10 questions by marking the corresponding letter. Part three was in-depth reading requiring students to read two passages of around 370 words each and answer multiple choice questions.

Reading Strategies Questionnaire. The thirty-item reading strategies questionnaire was originally developed by Mokhtari and Sheorey (2002). The reliability coefficient (Cronbach's alpha) of Mokhtari and Sheorey's reading strategies questionnaire reached 0.93 . And their reading strategies questionnaire was structural validity in measuring ESL learners' meta-cognition in reading (Mokhtari \& Sheorey, 2002: pp. 3-4). Their questionnaire comprises 30 5-point Likert scale (from 1 (never) to 5 (always)) items measuring three broad categories of reading strategies: global reading strategies, support strategies and problem-solving strategies. Mokhtari and Sheorey's reading strategies questionnaire was adopted in this study. In this study, both pre- and post-tests were implemented on CG and EG with this reading strategies questionnaire.

Interview. To find out non-English-major graduates' response to this new approach to non-English-major graduates' English reading, their attitudes, problems, perception of benefits and predicted future use of this method were gathered through an interview on the KWL plus model of meta-cognitive reading strategies in IBLL with non-English-major graduates in EG in the last English class. They were totally free to decide on their own whether to participate in attending the interview.

At the end of the semester, the collected data of subjects' pre- and post-reading test scores and the questionnaire results were processed with SPPS15.0. An independent samples t-test was used to find if there were differences between EG and CG pre- and post-tests. And a paired samples t-test was used to analyze any perceived differences in meta-cognition and strategy use of EG in IBLL before and after the experiment. Data of the inter- 
view were analyzed and categorized according to questions asked in the interview.

\section{Results}

The findings in this study were shown in four parts. Part One was reading test results of CG and EG. Part Two compared subjects' meta-cognitive awareness and reading strategy use. Part Three was that there are significant differences between males and females, as a teacher-dominated approach with CG is compared with the KWL plus model of reading strategy instruction in IBLL with EG. Part Four examined perceptions of the meta-cognitive strategy instruction in IBLL from non-English-major graduates in EG.

\subsection{KWL plus Strategy Instruction in IBLL and Reading Comprehension}

As shown in Table 1, the impact of the KWL plus model of meta-cognitive strategy instruction on non-Englishmajor graduates reading comprehension was measured by comparing reading test (CET 6) scores between CG and EG in the pre- and post-tests. In the pre-tests, there was no significant difference between CG $(\mathrm{M}=138.24$, $\mathrm{S}=20.12)$ and $\mathrm{EG}(\mathrm{M}=136.56, \mathrm{~S}=18.99)$ in reading comprehension ability, $\mathrm{P}=0.25$. However, in the post-test, there was a significant difference between $C G(M=139.29, S=18.00)$ and $E G(M=147.29, S=$ 13.88) in reading comprehension ability, $\mathrm{P}=0.04$.

\subsection{Instructional Effects of KWL plus on EG Subjects' Meta-Cognition in IBLL}

The questionnaires on the KWL plus model of meta-cognitive reading strategies instruction in IBLL before and after the intervention were used to measure the effects of meta-cognitive strategies (support strategies, global strategies and problem-solving strategies) training in IBLL on non-English-major graduates of EG in reading comprehension. As shown in Table 2, non-English graduates in EG had improved their meta-cognitive reading strategy use in all three-sub-category levels. Among these three sub-categories, there were significant differences for improvements in use of support strategies $(\mathrm{P}=-6.35)$ and global strategies $(\mathrm{P}=-4.45)$. The improvement in use of problem-solving strategies was also higher after the KWL plus model of meta-cognitive strategies instruction in IBLL.

\subsection{Results of the T-Test about Males and Females in CG and EG}

As shown in Table 3, there were significant differences between males and females in CG and EG. Males $(\mathrm{P}=$ 0.003) suggested that there was the significant difference between CG and EG and females $(P=0.002)$ suggested that there was the significant difference between CG and EG.

Table 1. Effects of the KWL plus model of meta-cognitive strategy instruction on non-English-major graduates reading comprehension.

\begin{tabular}{cccccc}
\multirow{2}{*}{ Groups } & \multirow{2}{*}{ Tests } & \multicolumn{2}{c}{ Pre-test } & \multicolumn{2}{c}{ Post-test } \\
\cline { 2 - 5 } & & M & S & M & S \\
\hline \multirow{2}{*}{ CG } & 138.24 & 20.12 & 139.29 & 18.00 \\
EG & 136.56 & 18.99 & 147.29 & 13.88 \\
\hline
\end{tabular}

M stands for Mean; S stands for standard deviation; ${ }^{*} \mathrm{P}<0.05$.

Table 2. Instructional effects of KWL plus on EG subjects' meta-cognition in IBLL.

\begin{tabular}{cccccc} 
& \multicolumn{1}{c}{ Tests } & \multicolumn{2}{c}{ Pre-instruction } & \multicolumn{3}{c}{ Post-instruction } \\
$\begin{array}{c}\text { Meta-cognitive } \\
\text { Strategies }\end{array}$ & M & S & M & S \\
\cline { 2 - 6 } Support strategies & 2.93 & 1.10 & 3.49 & 0.87 \\
Global strategies & 3.05 & 0.99 & 3.44 & 0.81 \\
Problem-solving strategies & 3.29 & 0.81 & 3.42 & 0.72 \\
\hline
\end{tabular}

M stands for Mean; S stands for standard deviation; ${ }^{* *} \mathrm{P}<0.01$. 
Table 3. Results of the t-test about males and females in CG and EG.

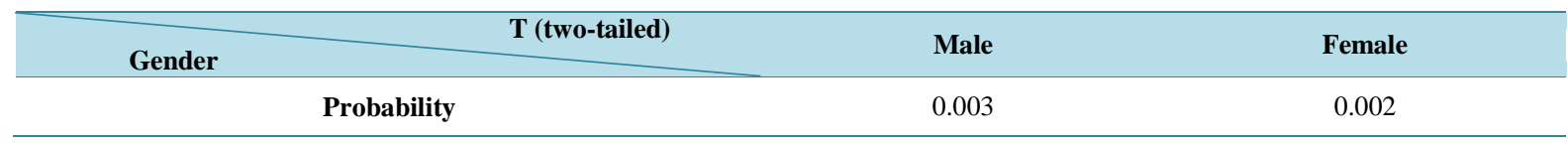

\subsection{Perceptions of the Meta-Cognitive Strategy Instruction in IBLL from Non-English-Major Graduates in EG}

The interview on the meta-cognitive strategy instruction in IBLL from non-English-major graduates in EG was administered to all EG subjects at the end of the semester to examine their response for this integrated training and to identify the possible benefits and problems of this program.

Among the 41 subjects in EG, 30 indicated that it was good to do English reading this way and they were also willing to try this way in the future. The main benefits of employing KWL plus in reading in IBLL were reflected at three aspects. First, students were instructed by the KWL plus model of meta-cognitive strategies with the support of IBLL, they became active readers and independent thinkers because more questions related to the reading material were generated before they read the reading materials and they could be more easily to communicate or discuss with classmates or other people on the reading materials with the help of IBLL. Second, students could increase their meta-cognitive knowledge about themselves, the tasks and the reading strategies they should employ. Subjects said they also learned to regulate their strategy use through continuous attention to their reading process. Third, duo to KWL plus strategy training in IBLL, they not only visualized and consolidated their reading comprehension through semantic guide and summarization of the reading materials, also applied the KWL plus model of meta-cognitive strategies into the more new reading materials and communicated with more people about KWL plus strategies with the help of IBLL.

\section{Discussion}

One of the purposes in this study is to know if the KWL plus model of meta-cognitive reading strategy instruction through IBLL can improve non-English-majored graduates’ reading comprehension. Subjects’ improvement in reading comprehension shows the important role of meta-cognition plays in reading comprehension. This study is in line with other studies that regarded meta-cognitive strategy instruction as a method to help students gain better comprehension in ESL or EFL reading (e.g., Carrell et al., 1989; Boulware-Gooden et al., 2007).

The significant differences in meta-cognitive strategy use demonstrated in the pre- and post-questionnaire also suggest that the KWL plus model in IBLL is an effective approach to meta-cognitive strategy instruction. Chamot (2009) identified good language learners as active learners who monitored their comprehension by continuous self-questioning, related new information to their own prior knowledge, knew how to make use of their prior knowledge, and made inferences about possible meanings. The KWL plus approach promotes learners' active involvement in their reading process via pre-, during- and post- reading activities. The meta-cognitive strategy instruction in IBLL in this study turned out favorable results, no matter whether we compare EG's questionnaire results pre- and post-instruction or EG and CG English reading test scores at the end of the instruction. The questionnaires outcomes show that non-English-major graduates in EG could successfully learn meta-cognitive strategies and apply the KWL plus model of meta-cognitive strategies in new reading materials in IBLL. The results in this study agree with Grabe's (2009) claim that strategy instruction need not necessarily follow the one-time-one- strategy pattern.

After training by the model of KWL plus of meta-cognitive strategies, male and female non-English-major graduates in EG successfully learn and apply the meat-cognitive strategies in new reading materials in IBLL, they perform better in reading comprehension, compared with male and female non-English-major graduates in CG. And there are significant differences between Males and Females in CG and EG.

Non-English-major graduates in EG generally holding positive response for the KWL plus model of meta-cognitive strategy training program suggest that the incorporation of meta-cognition training and IBLL into regular EFL curriculum is a worth try. Graduates need read more academic documents related to their majors, the KWL plus model of meta-cognitive strategy instruction with the support of IBLL promote their reading skills and reading comprehension. Although subjects in EG could learn the KWL plus model of meta-cognitive strategies with the support of IBLL, they also need the help from teaches. Teachers need to help students build 
background knowledge if it is not presented (Duke, 2004: p. 42), and achieve the balance between explicit strategy instruction, language learning and use of IBLL.

\section{Limitations and Suggestions for Further Research}

Though the present study has provided a comparatively detailed description of the KWL plus model of reading strategy instruction through IBLL applied among some first-year non-English-majored graduate students, there are still some limitations of the study. Having the limitations in mind, suggestions for further research, therefore, can be put forward at the same time in order to achieve a lot thorough understanding of the KWL plus model of reading strategy instruction through IBLL.

Firstly, being time limitation (only a term) and other practical restrictions such as the subjects in the study consisted of only 162 non-English-majored graduate students in one university need to be broadened in further research.

Secondly, the instruments used to investigate non-English-majored graduate reading strategy instruction with the KWL plus model through IBLL involve structured questionnaire and tests. The study would be much better, if it were combined with other instruments such as observation, verbal report. More instruments should be used in investigation in further research.

Finally, the KWL plus model of reading strategy instruction through IBLL applied in non-English-majored graduate English reading can improve non-English-majored graduate students' English reading, but the KWL plus model of reading strategy instruction through IBLL also works for other subjects such as undergraduate students, we need further research.

Despite of the restraints of the study, it is hoped that it can offer some guidelines for further research on the KWL plus model through IBLL applied in English teaching.

\section{Conclusion}

There are 82 non-English-major graduates from Yangtze University to participate in this study. They are 41 nonEnglish-majored graduate students in the control group (CG) and 41 non-English-majored graduate students in the experimental group (EG). The results showed that 1) compared with a teacher-dominated approach for CG, internet-based language laboratory with KWL plus model meta-cognitive reading strategy instruction for EG did a better job in enhancing students' reading skills; 2) There were significant differences between males in CG and EG and females in CG and EG; 3) Students in EG held the positive response for the combined instruction. The incorporation of the KWL plus model of meta-cognition strategy instruction and IBLL into the regular EFL curriculum is a better try to improve their reading comprehension.

\section{References}

Auerbach, E., \& Paxton, D. (1997). It's Not the English Thing: Bringing Reading Research into the BSL Classroom. TESOL Quarterly, 31, 237-261. http://dx.doi.org/10.2307/3588046

Anderson, N. J. (2002). The Role of Meta-Cognition in Second Language Teaching and Learning. ERIC Digest (Vol. April 2002). Washington DC: Center for Applied Linguistics.

Boulware-Gooden, R., Carreker, S., Thornhill, A., \& Joshi, R. M. (2007). Instruction of Meta-Cognitive Strategies Enhances Reading Comprehension and Vocabulary Achievement of Third-Grade Students. The Reading Teacher, 61, 70-77. http://dx.doi.org/10.1598/RT.61.1.7

Carr, E., \& Ogle, D. (1987). KWL Plus: A Strategy for Comprehension and Summarization. Journal of Reading, 30, 626631.

Carrell, P. L., Pharis, B., \& Liberto, J. (1989). Meta-Cognitive Strategy Training for ESL Reading. TESOL Quarterly, 23, 647-678. http://dx.doi.org/10.2307/3587536

Chamot, A. U. (1995). Learning Strategies and Listening Comprehension. In D. Mendelsohn, \& J. Rubin (Eds.), A Guide for the Teaching of Second Language Listening (pp. 13-30). San Diego: Dominie Press.

Grabe, W. (2009). Reading a Second Language: Moving from Theory to Practice. New York: Cambridge University Press.

Duke, N. (2004). The Case for Informational Text. Educational Leadership, 61, 40-44.

Huang, J. H., \& Newbern, C. (2012) The Effects of Meta-Cognitive Reading Strategy Instruction on Reading Performance of Adult ESL Learners with Limited English and Literacy Skills. Journal of Research and Practice for Adult Literacy, Sec- 
ondary, and Basic Education, 1, 66-77.

McKeown, R. G., \& Gentilucci, J. L. (2007). Think-Aloud Strategy: Meta-Cognitive Development and Monitoring Comprehension in the Middle School Second-Language Classroom. Journal of Adolescent \& Adult Literacy, 51, 136-147. http://dx.doi.org/10.1598/JAAL.51.2.5

Ustatia, M. K., \& Ismail, I. S. (2013). Challenges Faced by Malaysian Polytechnic English Lecturers in Utilizing Digital Language Lab. Procedia—Social and Behavioral Sciences, 90, 365-373. http://dx.doi.org/10.1016/j.sbspro.2013.07.104

Mokhtari, K., \& Sheorey, R. (2002). Measuring ESL Students’ Awareness of Reading Strategies. Journal of Developmental Education, 25, 2-10.

Önkaú, N. A. (2009). Poetry Teaching in Laboratory Setting. Procedia-Social and Behavioral Sciences, 1, 590-595. http://dx.doi.org/10.1016/j.sbspro.2009.01.106

Ogle, D. (1986). K-W-L: A Teaching Model That Develops Active Reading of Expository Text. The Reading Teacher, 39, 564-570. http://dx.doi.org/10.1598/RT.39.6.11

Ogle, D. (2007). Coming Together as Readers: Building Literacy Teams (2nd ed.). Thousand Oaks, CA: Corwin Press.

Ogle, D. (2009). Eating Contexts for Inquiry: From KWL to PRC2. Knowledge Quest, 38, 56-61.

Oxford, R. (2001). Language Learning Styles and Strategies. In M. Celce-Murcia (Ed.), Teaching English as a Second or Foreign Language. Boston, MA: Heinle and Heinle.

Rusciolelli, J. (1995). Student Responses to Reading Strategies Instruction. Foreign Language Annals, 28, $262-273$. http://dx.doi.org/10.1111/j.1944-9720.1995.tb00791.x

Rubin, J. (2001). Language Learner Self-Management. Journal of Asian Pacific Communication, 11, 25-37. http://dx.doi.org/10.1075/japc.11.1.05rub

Shang, H. F., \& Chang-Chien, I. J. (2010). The Effect of Self-Questioning Strategy on EFL Learners’ Reading Comprehension Development. The International Journal of Learning, 17, 40-54.

Shen, J. (1999). Learner Anxiety and Computer-Assisted Writing. CALL-EJ, 3, Online Published. http://www.lerc.ritsumei.ac.jp/callej/3-2/shen.html

Sullivan, N. (1993). Teaching Writing on a Computer Network. TESOL Journal, 3, 34-35.

Vandergrift, L., \& Tafaghodtari, M. (2010). Teaching L2 Learners How to Listen Does Make a Difference: An Empirical Study. Language Learning, 60, 470-497. http://dx.doi.org/10.1111/j.1467-9922.2009.00559.X

Wang, Y. W., Wu, L. G., \& Sun, D. X. (2003). Integrating CALL in Teaching Intensive Reading at Graduate Level. Teaching English in China, 26, 101-107.

Warschauer, M., \& Healey, D. (1998). Computers and Language Learning: An Overview. Language Teaching, 31, 51-71. http://dx.doi.org/10.1017/S0261444800012970

Wenden, A. L. (2000). Learner Development in Language Learning. Applied Linguistics, 23, 32-55. http://dx.doi.org/10.1093/applin/23.1.32

Yi, L., \& Gao, X. Y. (2011). Practice of Autonomous Learning Mode under the Language Laboratory Environment. Research and Exploration in Laboratory, 7, 327-329. 